\title{
Wildlife-Human Conflicts in Some Parts of Bangladesh
}

\author{
M Ashraful Kabir* \\ Department of Biology, Saidpur Cantonment Public College, Nilphamari, Bangladesh
}

Corresponding Author: M Ashraful Kabir, Department of Biology, Saidpur Cantonment Public College, Nilphamari, Bangladesh

\begin{abstract}
Wildlife is the natural creature of the nature. It has no education, no morality as well as complete sympathy on human. Carnivorous animals such as tiger and bear attack in Bangladesh are very common. In Sundarbans and its adjacent areas there are lots of incidences of tiger attack. Royal Bengal Tiger (Panthera tigris) and Asian Elephant (Elephas maximus) in Sundarbans and Asian Black Bear (Ursus thibetanus) in Chittagong Hill Tracts are common animal attack on human. Illegal entry in those forests, hunting or killing and deforestation are the main causes for these attacks. Tiger attack was the first then elephant and finally bears. Unfortunately, due to tiger attack human death record was common but for elephant or bear human seriously injured which were fatal for them. Tiger can be man eater, elephants are man-screamer and bears are being considered man-injurious. For avoiding such conflicts we may apply some methods.
\end{abstract}

Keywords: Conflict; Wildlife; Bangladesh.

\section{INTRODUCTION}

Co-existence workshop at the 5th Annual World Parks Congress (8-17 September 2003, Montreal) defined 'Human-wildlife conflict occurs when the needs and behavior of wildlife impact negatively on the goals of humans or when the goals of humans negatively impact the needs of wildlife.' A 2007 review by the US Geological Survey defines human-wildlife conflict in two contexts; firstly, actions by wildlife conflict with human goals, and, secondly, human activities threaten the safety and survival of wildlife. The Government of Yukon defines human-wildlife conflict simply, but through the less of damage to property. The history of human-wildlife conflicts is very ancient. Fossil of young Australopithecus africanus thought to be killed by eagle and mans' skull were found in egg shell and remains of the small animals. Horned Crocodile (Crocodylus anthropophagus) in Plio-Pleistocene period whose fossil remains have been recorded from Olduvai Gorge, was the largest predator encountered by man indicated crocodile bite marks. In the development of human socialism and agriculture and animal husbandry increased the scope of conflict. Wild herbivores competed with domestic animals for human welfare. The livestock attracted various wild animals to enter human residences. Human activities within the forest eliminate real habitat of animals which impact wild animals adversely. A lot of papers were completed on wildlife attacks on human (Hoare, 1995; Nchanji, 2002). In this regard, the elephants are more complained animals (Naughton-Treves, 1996). The wild pig damages small amount of crops (Nchanji, 2002). For controlling the pig thorn barrier, noisemaker and scarecrow for birds are effective. For controlling the disasters of human-wildlife conflicts social scientist and wildlife biologists have a lot of duties on human and nature. In most parts of Zimbabwe for protecting such attacks the electric fences have applied (WWF, 1998, 2000). Not only human or crops but also the livestock of the farmers are destroying several wildlife (Hill 1998; Naughton-Treves, 1996). Primates are more intelligent and fast wild animals which can't easily controlled. Within the primate group if the alpha male dies the total group is stopped of destroying ability to crops. Normally pig, elephant and buffalo are attacked at night (UNP 1995, 1996). Baboons are notorious, intensive and crop raiders (Mwesigye, 1996). In fact, depending on controlling measure bird pests are good because it comes early in the morning and evening. Whereas, baboon has no exact time to come and they damage the crops than eat (Hill, 2002). Buffalo is the major pest (RRAM, 1987) and elephants are second in other parts of Africa (Thouless and Sakwa, 1995; Lahm, 1996; Tchamba, 1996). Noise and droppings of the crow are the problem of school-going students. In the year 1998 in New Jersey bear attacks were 29 home entry, 25 livestock kill, 40 pet attack and 34 
incidents involving aggressiveness. From 1970 bear killing is prohibited from the world (New Jersey Division of Fish and Wildlife, 2000). The objective of this study is to find out some major wildlife attacks on human and try to establish some protective methods from them.

\section{Materials AND Methods}

In Bangladesh beside railway station or any open places there some gypsies which are called bede. They catch wild animals especially snakes so conflicts or snake bites are very common for them. Monkey charmer is a part of our culture so that sudden attack may happen. Nowadays in our country 1-2 circus teams are continuing their show for recreation. In circus bear and elephant attack is common. In zoo many visitor come with casual dress and feed animals. Moreover, zoos are now considered a recreational place also so conflicts may arise. In this context, safari park is good for understanding or doing research on animals. In our Sundarbans many villagers and farmers are living adjacent forest. They have no rehabilitation to migrate another. Narrative research design (when real life problems are investigated) and questionnaires enriched the data of this research.

Table1. Methods of wildlife protection with its advantage and disadvantage

\begin{tabular}{|c|c|c|}
\hline Method & Advantage & Disadvantage \\
\hline Electric fence & Quick action & Dangerous to human \\
\hline Trap & Low cost & $\begin{array}{l}\text { Missing; This is prohibited for animals' } \\
\text { pain }\end{array}$ \\
\hline Poison & Hunger animals take as food & $\begin{array}{l}\text { For environmental pollution this method } \\
\text { is not allowed }\end{array}$ \\
\hline Barrier & $\begin{array}{l}\text { Thorn and vegetation barrier preserves } \\
\text { natural beauty }\end{array}$ & In fact, this is injurious to human \\
\hline Sound & Very easy for making & Create sound pollution \\
\hline Scarecrow & Easy method & In the long run, animals are habituated \\
\hline Killing/Hunting & Result is totally effective & This is very painful for animals \\
\hline Translocation & $\begin{array}{l}\text { In any particular place this method is } \\
\text { appropriate }\end{array}$ & Not suitable in every places \\
\hline Trench & Intact animal body is captured in hole & $\begin{array}{l}\text { Unfortunately, human and vehicle are } \\
\text { fallen in that trench }\end{array}$ \\
\hline Firing & Animals get fear and escape & Make bushfire \\
\hline Dried pepper & Stop quick attack & Dangerous to human eye \\
\hline $\begin{array}{l}\text { Dog (biological } \\
\text { control) }\end{array}$ & Dog is a faithful and intelligent animal & Time consuming method \\
\hline
\end{tabular}

Table2. Conflicts and considering pests in Bangladesh

\begin{tabular}{|c|c|c|c|}
\hline Animals & Anthropopest & Agropest & Amphipest \\
\hline Tiger & $\sqrt{ }$ & $\times$ & $\sqrt{ }$ \\
\hline Elephant & $\sqrt{ }$ & $\sqrt{ }$ & $\times$ \\
\hline Bear & $\sqrt{ }$ & $\sqrt{ }$ & $\times$ \\
\hline Rat & $\times$ & $\times$ & $\times$ \\
\hline Palm Civet & $\sqrt{ }$ & & 33.33 \\
\hline Cobra & \multicolumn{2}{|c|}{66.67} & \\
\hline Total $\%)$ &
\end{tabular}

*Anthropopest $=$ attack on human; agropest $=$ damage crops ; amphipest $=$ pest for human and crops 


\section{RESUltS}

\subsection{Major Attacks in Bangladesh}

Sundarbans of Bangladesh and India are estimated from 1947 to 1983 to kill people by Royal Bengal Tiger 0-50 per year. Once in Sundarbans there are 500 tigers which regularly killed 50-60 people per year. Tigers are extremely powerful and for destroying small wooden boats of the fishermen. After the natural calamity (Sidr) Bangladesh has lost tiger for traditional food sources. Fishermen and Bushmen created masks to wear on the back of head because tigers always attack from behind. Government officials have supplied wear stiff pads that rise up the back of the neck, to prevent biting into the spine. Another possibility is that due to cyclones of India and Bangladesh human killed thousands which were eaten by tigers. Humans travel inside the Sundarbans on boats gathering honey and fishing making them easy prey. Fishermen in small boats have been attacked due to strong abilities of tigers swimming. Villagers occasionally have released livestock into the forest an alternative food source and discourage them from entering the villages (google.com, tiger attack in Sundarbans). In the Sundarbans mangrove forest lying between India and Bangladesh, 50 people were killed by tigers in 2009-2010. In 1975-1985, 425 people were reportedly killed by tigers in the Indian portion of Sundarbans and another 187 were killed by tigers in Bangladesh (McDougal, 1991). In some areas, tigers themselves have altered their nocturnal activity due to avoid human-tiger conflict (Hutchins, 2013). Tigers are adapted to a wide range of environment (Schaller, 1967; Sunquist, 1981; Seidensticker and McDougal, 1993). Tiger hunts age classes animals not just the old or very young (Sunquist and Sanquist, 2002). Tigers' fat is used for leprosy and rheumatism (Vijan and Gurunathan, 1994). Sundari Tree (Heritiera fomes) (less saline area) and Milky Mangrove (Excoecaria agallocha) (more saline area) are decreasing day by day from Sundarbans (Khan, 2004). Crow and vulture are the advertisers of tiger locality (Schaller, 1972; Johnsing, 1983; Karanth and Sunquist, 1995). Sundarbans of Bangladesh and India is the highest level of tiger-human conflict in the world (Blanford, 1891; Siddiqui and Choudhury, 1987; Chakrabarti, 1992). November to February (77\%) which is the peak breeding season of tiger and that time 73\% male tigers are killed by people. Only 3\% tigers in Sundarbans are man-eater (Hendrichs, 1975). Man-eater mothers' cubs are habituated to prey human (Nyhus and Tilson, 2004). In Bandarban, Bangladesh a man was killed by an Asiatic Black Bear in Nachalongpara area under Rowangchhari upazila. The deceased was identified as Mong Ching U Marma who was 32 years old. Local sources said that the victim with some others went to Bardarban forest for hunting. They saw a bear and shot it. After a while, the injured bear attacked that man, leaving him dead on the spot and injured two others (www.google.com, Bear attack in Bandarban). Most of the Asian Elephant attack occurred in Bangladesh in winter and rainy season by its group. In Bangladesh Asian Elephant are the main mammalian pest, Rhinoceros in Nepal and Lion in Tanzania (Packer et al., 2007; Gurung and Gossow, 2004). Two types of elephants are found worldwide depending on its migratory nature- local migratory and cross-border migratory. Old and very active female are considered a leader of the herd. There are three subspecies of Asian Elephant- Indian, Sri Lankan and Sumatran (Sarker and Roskaft, 2011). In Thailand the environment of elephant is good so that there are no conflicts with them. Most of the elephant attack in Bangladesh mainly in crop season (Banskota and Sharma, 1995). When an elephant reach in adolescent stage the bull are separated and live alone (Lee and Eltringham, 1991). Bull elephant are more aggressive than female (Hossen, 2013). During the time of cattle ranching by the farmers the elephants come out from the forest for collecting natural resources (Sarker, 2010). Bull attacks mainly at day and single but at night the group attack of the elephants were shown. In Sri Lanka in the year 1991-2001 75\% men, 13\% female and 12\% children were killed by elephant (Bandaras Tisdell, 2003) and in India out of 53 deaths $77 \%$ death by herd and 23\% by bulls (Sukumar, 2003). Dusk and dawn is the resting time of elephants so that time few attacks happen. 200 elephants die in India per year due to attack on human (Bist, 2002) and in Sri Lanka this is 150 (Perera, 2009). In nature elephants die fall from the hill, snake bites, electrocute, trapping and natural calamities (Hossen, 2013) (Table 1 and 2).

\subsection{Causes of Animal Attack}

Snake charmer: Bede is a small community of Bangladesh and catch snakes from the forests. Snake charming is very enjoyable to the people especially children. There are many people who became dead for this act. Bedes are known to rub the fangs of the poisonous snake or cut the poison gland. Removed poison gland those snakes are not live properly because venom is its strong digestive juice. Wildlife-Human Conflicts in Some Parts of Bangladesh 
Monkey charmer: This is popular than snake charmer. Monkeys leap on the master is very attractive. Otherwise the facial appearance of monkeys is similar with human and its friction ridges on the face are more scientific than other animals. During this act monkeys get fear and conflict may happen.

In circus: Circus is the great recreational item of the world. Here a lot of animals are engaged for human recreation. Tiger, horse, donkey, monkey, civet, deer are available in circus team. Due to public gathering and noise the conflict of the animals are very common. Domestic or pet animals can introduce in circus team for avoiding those attacks. Declaring to the audience people lest use of artificial light and unwanted noise which is good for their safety. A report showed in India and Bangladesh during the year 1950 to 2005, 18 people killed by elephant, 15 elephant killed by people and 1 lion killed by elephant. Famous elephant trainer Axel Gautier was killed by his elephant in Florida on May 1993 (See: incident(s), Lawsuit filed). From 1978 to 2001 circus animal incidents were happened in Florida and New York with 4 incidents and 3 in California and Moscow. During the performing on circus stage and handling of animals 10 peoples and 6 animal trainer killed by elephants, 3 bites by bear, 16 injuries and 3 attacks were occurred. On the other hand 8 elephant, 2 bear, 1 Arabian horse, 1 donkey were killed by police when it was threat to human. Both Asian and African elephants are banned in circus in 1990 by CITES (Updated March, 2001). Poachers, illegal wildlife trader, snake charmers and gypsies (bede) are involved with the supplying of the wild animals and they sell it with a small amount of money to the circus team. For training purpose the trainer use whip or hook so that animals get frightened and attacks may happen. If we deduct the animal portion from the circus it will be better for avoiding those severe attacks on human (Kabir, 2013).

Slaughtering: We may get protein from the plant sources. Most of the dangerous diseases in human come from animal origin. HIV, plague, bird flu, mad cow, malaria all are animal concerning diseases. For taking animal meat we need to slaughter those animals especially cow and goat. The cows' horn sometimes may fatal to the people.

Capturing: For animals meat human first captured that animals from the nature. It was very adventurous, challenging and life-threatened. The scenario of the capturing animals by trapping is very common is some English movies where conflict is must and dangerous if that animals are carnivorous.

Zoo keeping and riding: Feeding of zoo animals and poor enclosure animals may dangerous for human life. In Bangladesh there are some zoos with recreational park that makes huge gathering and more sound and the animals feel uneasy so that conflict occurs. In zoos ride on elephant and horse may dangerous sometime.

During research: Research is must for welfare of the animals but need to maintain huge scientific precautions in such animal centres.

For pet and domestication: At the first stage of domestication it is not in feed or with the empty stomach or new environment it shows ultimate aggressiveness. An animal which was born in jungle is not easy to remove its wilderness from the brain easily.

Deforestation: Habitat is our fundamental right but lest destroying the habitat of wild animals. Most of tiger attacks in Bangladesh were found for deforesting.

In breeding season: Most of the animals are got tempered in breeding season. In case of mammals, birds and reptiles are more ferocious in their breeding season. This time it seems other animals are enemy of their eggs, nests and young. We should know the exact breeding season of the animals for avoiding those conflicts. Cobra biting is very common in Bangladesh in breeding season. 
Very colourful dress: Animals get fear if they see very colourful dresses of the peoples. In animals some are colour blind, half colour blind and some converted red into strange black. So, the animals attack to human. Always try to put very light coloured dresses if you visit any animal concerning areas.

Diseased animals: Diseased animals are not normal with its behavior. Need to understand the observed animals are healthy or sick. Newly introduced animals may show their anxiety and depression. Visitors should apply their sympathy to them.

Natural calamities: Thunderstorm, rainfall, landslides and earthquake the animals feel unsecure and become angry.

Forest-edge human habitat: Lack of own or purchased land the forest area is utilizing for human shelter. This is one of the root causes of such attacks. In our Sundarbans and hilly areas most attacks happened under this section.

\section{DISCUSSION}

Chief confliction causes for food between man and animal. In large carnivores such as lions, jaguars, leopards, wolves, and crocodilians kill and eat domestic livestock. In Africa and Asia, elephants kill hundreds of people each year. It is estimated that 10,000-12,000 people die in India by poisonous snakes per year. In North America, fatal encounters very common between humans and grizzly bears (Herrero, 1985). Specifically, the use of domestic dog to protect livestock from predators has become popular worldwide. In Brazil, electric fences are used to prevent livestock from jaguars and wolves across the western and north-central U.S. Large predators act as key to the health of functioning ecosystems (Unger, 2008). The Federal Aviation Administration (FAA) maintains a database on wildlife strikes on aircraft contains records of 82,057 strikes involved birds (97.5\%) (Hutchins, 2013). During crossing roads deer are injured by motorists. Wildlife have huge impacts on human welfare are ecological, cultural, health, safety, psychological, social and economic. Various agencies, NGOs, local government, community, and wildlife officials can take initiatives (Decker et al., 2002). Animal movements' calendar, conflict seasons and crop ripening period will be helpful for forecasting the bad incidents in any forest. Animals' footprints, teeth impression on bark, dung, hairs can be helpful to jungle survivor (Nchanji, 2002). Using contraceptives for controlling wild animals is now experimental. Weekly seminar is important for sharing the condition of zoo animals and infrastructure. Make a special list of carnivore or man-eating animals. Awarded wildlife biologists in front of the audience; from this people will be initiated to preserve those animals and concern with animal attacks. For the proper maintenance of animals, if possible, employ different animal experts mainly in three groups- reptilia, aves, and mammalia.

\section{REFERENCES}

[1] Bandara, R. and Tisdell, C. 2003. Comparison of rural and urban attitudes to the conservation of Asian elephants in Sri Lanka: empirical evidence. Biological Conservation 110: 327-342.

[2] Banskota, K. and Shrama, B. 1995. Tourism for mountain community development: case study report on the Annapurna and gorkha Regions of Nepal. International Centre for Integrated Mountain Development, Kathmandu. pp. 233.

[3] Bear attack in Bandarban, 2014. May 5 Bdst. http://www.banglarmookh.com/?p=44686

[4] Bist, S. S. 2002. An overview of elephant conservation in India, The Indian Forester 128:121-136.

[5] Blanford, W. T. 1891. Fauna of British India: Mammalia. Taylor and Francis, London.

[6] Chakrabarti, K. 1992. Man-eating tigers. Darbari Prokashan, Calcutta.

[7] Circus and ride elephant incidents. See- incident; incidents; lawsuits filed; lawsuit file- child's family.

[8] Decker, D. J., Lauber, T. B. and Siemer, W. F. 2002. A practitioners guide: human-wildlife conflict management. Northeast Wildlife Management, USA.

[9] Gurung, M. K. and Gossow, H. 2004. Human dimension in One-horned Rhinoceros Conservation in Royal Chitwan National Park Nepal (unpublished master's thesis). pp: 121.

[10] Hendrichs, H. 1975. The status of the tiger Panthera tigris (L. 1758) in the Sundarbans mangrove forest (Bay of Bengal). Saugetierk. Mitt. 23(3): 161-199. 
[11] Herrero, S. 1985. Bear Attacks: Their Causes and Avoidance. Piscataway, NJ: Winchester Press.

[12] Hill, C. M. 1998. Conflicting attitudes towards elephants around the Budongo Forest Reserve, Uganda. Environmental Conservation 25(3): 244-250.

[13] Hill, C. M. 2002. People, crops and wildlife: a conflict of interests. Dept. of Anthropology. Oxford Brookes University, Oxford UK.

[14] Hoare, R. 1995. Options for the control of elephants in conflict with people. Pachyderm 19:54-63.

[15] Hossen, A. 2013. Human-elephant conflict in Bangladesh; causes and intensity of fatalities. Dept. of Biology, Norwegian University of Science and Technology, Norway.

[16] Hutchins, D. M. 2013. Human-Wildlife Conflict: An Interview with Dr. Michael Hutchins. Grizzly People, University of Alaska, posted Jordan Carlton Schaul.

[17] Johnsingh, A. J. T. 1983. Large mammalian prey-predators in Bandipur. J. Bombay Nat. Hist. Soc. 80: 157.

[18] Kabir, M. A. 2013. Circus tradition of Bangladesh and fate in its animals. South Pacific Journal of Pharma and Bio Science (1): 51-57.

[19] Karanth, K. U. and Sunquist, M. E. 1995. Prey selection by tiger, leopard and dhole in tropical forests. J. Anim. Ecol. 64: 439-450.

[20] Khan, M. M. H. 2004. Ecology and conservation of the Bengal Tiger in the Sundarbans mangrove forest of Bangladesh. Dept. of Anatomy. University of Cambridge, UK.

[21] Lahm, S. A. 1996. A nationwide survey of crop raiding by elephants and other species in Gabon. Pachyderm 21: 69-77.

[22] Lee, P. and Eltringham, S. K. 1991. Social life. The illustrated encyclopedia of elephants: from their origins and evolution to their ceremonial and working relationship with man. pp: 48-63.

[23] McDougal, C. 1991. Man-eaters. pp. 204-207 in Seidensticker, J. and Lumpkin, S. (eds.) Great Cats: Majestic Creatures of the Wild. Emmaus, PA: Rodale Press.

[24] Mwesigye, 1996. Crop raiding by baboon (Papio anubis) around Bwindi Impenetrable National Park South West Uganda. Unpublished MSc. Thesis, Makerere University.

[25] Naughton-Treves, L. 1996. Uneasy neighbors: wildlife and farmers around Kibale National Park, Uganda, University of Florida: Unpublished PhD.

[26] Nchanji, A. 2002. Crop damage around northern Banyang-Mbo Wildlife Sanctuary, WCS Cameron.

[27] Nyhus, P. J. and Tilson, R. L. 2004. Characterizing human-tiger conflict in Sumatra, Indonesia: implications for conservation. Oryx 38(1): 68-74.

[28] Packer, C., Ikanda, D. K., Kissui, B. and Kushnir, H. 2007. The ecology of lion attacks on humans in Tanzania. Nature and Fauna 21(2): 10-15.

[29] Perera, B. M. A. O. 2009. The human-elephant conflict: A review of current status and mitigation methods. Gajah 30:41-52.

[30] RRAM, 1987. Ruhengeri and its Resources. An Environmental Profile of the Ruhengeri Prefecture. Unpublished report for the Ruhengeri Resources and Management Project, Kigali, Rwanda.

[31] Sarker, A. H. M. R. 2010. Human-wildlife conflict: a comparison between Asia and Africa with special reference to Elephant. Emmanuel J. Gereta and E. Roskaft (editors). Conservation of

[32] Natural Resources, Some African \& Asian Examples, Tapir academic press, NTNU. pp: 186-210.

[33] Sarker, A. H. M. R. and Roskaft, E. 2011. Human attitudes towards the conservation of protected

[34] areas: a case study from four protected areas in Bangladesh. Oryx 45 (3): 391-400.

[35] Schaller, G. B. 1972. The Serengeti lion: a study of predator-prey relations. University of Chicago Press, Chicago.

[36] Schaller, G. B. 1967. The deer and the tiger. University of Chicago Press, Chicago.

[37] Seidensticker, J. and McDougal, C. 1993. Tiger predatory behaviour, ecology and conservation. Symp. Zool. Soc. Lond. 65: 105-125. 
[38] Siddiqui, N. A. and Choudhury, J. H. 1987. Man-eating behaviour of tigers (Panthera tigris Linn.) of the Sundarbans - twenty-eight years' record analysis. Tigerpaper 14: 26-32.

[39] Sukumar, R. 2003. The living elephants: evolutionary ecology, behavior and conservation. Oxford University Press, New York, USA.

[40] Sunquist, M. E. 1981. Social organization of tigers (Panthera tigris) in Royal Chitwan

[41] National Park, Nepal. Smithsonian Contrib. Zool. 336: 1-98.

[42] Sunquist, M. E. and Sunquist, F. C. 2002. Wild cats of the world. University of ChicagoPress,

[43] Chicago and London. pp. 345-372.

[44] Tchamba, M. N. 1996. History and present status of the human/elephant conflict in the Waza- Logone Region, Cameroon, West Africa. Biological Conservation 75: 35-41.

[45] Thouless, C. R. and Sakwa, J. 1995. Shocking elephants: fences and crop raiders in Laikipia district, Kenya. Biological Conservation, 72: 99-107.

[46] Tiger attack in Sundarbans. http://en.wikipedia.org/wiki/Tiger_attacks_in_the_Sundarbans

[47] Uganda National Parks (UNP), 1995. Bwindi Impenetrable National Park Management Plan 1995 - 1999.

[48] Uganda National Parks (UNP), 1996. Mgahinga Gorilla National Park Management Plan 1996-2000.

[49] Unger, K. 2008. Managing a charismatic carnivore. The Wildlife Professional 2(4): 30-33.

[50] Updated March, 2001. Animals and people at the circus: accidents, attacks, animal abuse, and other incidents. The Human Society of the United States, 2100 L Street, NW, Washington DC.

[51] Vijan, P. and Gurunathan, K. 1994. Asian values to extinction. The Sun Magazine, 20December 1994, Kuala Lumpur.

Citation: M Ashraful Kabir., "Wildlife-Human Conflicts in Some Parts of Bangladesh)",International Journal of Research Studies in Zoology, vol. 5, no. 2, p. 8-14, 2019. DOI: http://dx.doi.org/10.20431/2454$941 X .0502002$

Copyright: (c) 2019 Authors. This is an open-access article distributed under the terms of the Creative Commons Attribution License, which permits unrestricted use, distribution, and reproduction in any medium, provided the original author and source are credited. 